\title{
CONGENITAL AGENESIS OF THE SPLEEN WITH CHRONIC ENTEROCOLITIS IN AN ADULT*
}

\author{
BY \\ J. GORDON ALEXANDER \\ From the Western General Hospital, Hull, Yorkshire
}

(RECEIVED FOR PUBLICATION MARCH 20, 1958)

\begin{abstract}
Persons with congenital absence of the spleen very rarely survive to adult life because they almost invariably have associated severe cardiovascular anomalies. There is no report in the literature of an adult who had chronic enterocolitis with secondary steatorrhoea in whom the possibility of absence of the spleen was suspected before death.
\end{abstract}

The exhaustive review of the subject of splenic agenesis by Putschar and Manion (1956) lists only 19 cases in adults. Fifteen of these had no other abnormalities, three had partial situs inversus, and one also had congenital disease of the heart. They also cite one case of a boy of 13 years, with no associated abnormalities, who died of injuries. Myerson and Koelle (1956) report a further case of an adult, with no other congenital abnormalities, who had a recurrent Waterhouse-Friderichsen syndrome. The case here reported is therefore the twenty-second case over the age of 3 years and the twenty-first in an adult.

An annotation in the British Medical Journal (1957) calls attention to this subject, there being an account in the same issue by Plowman (1957) of a case of a baby who, it should be noted, died from uncontrollable diarrhoea. The vast majority of the cases have been in babies, and, as France (1957) rather pertinently observes, "It would be surprising if it were not a relatively frequent incidental finding in any series of infantile deaths due to severe cardiac anomalies." Putschar and Manion (1956) list a total of 78 cases, a further 13 are quoted by Ivemark (1955), Bush and Ainger (1955) quote one, Towers and Middleton (1956) two, Nihoyannopoulos, Zannos, OeconomonMavrou, and Statherou (1956) one, France (1957) three, Leadbeater (1957) one, and Fadell, Corbett, and Carrasco (1957) one. The case reported here is therefore the one hundred and third.

* Read at a meeting of the East Mercian Branch of the Associavion of Clinical Pathologists on March 30, 1957.

\section{Case History}

The patient was a man aged 72 years. In the 1914-18 war he had had an appendicectomy operation. In 1949 he had a Salmonella tennessee bowel infection. He was discharged from hospital with no diarrhoea, but shortly afterwards began to have diarrhoea with intervals of constipation which lasted three to four days. On admission to hospital on October 24, 1956, he had diarrhoea and his stools contained blood and mucus. He had no pain, but was losing weight rapidly. He was emaciated, had a dry, scaly skin, and his general condition was poor. On October 25 the blood urea level was $38 \mathrm{mg}$./ $100 \mathrm{ml}$. Haematological investigations on October 29 showed: Haemoglobin, $80 \%$ (11.8 g./100 ml.), white cells 7,000/c.mm. (total neutrophils $55 \%$ $(3,850 /$ c.mm. $)$, band forms $15 \%(1,050 /$ c.mm. $)$, segmented forms $40 \% \quad(2,800 /$ c.mm. $)$, eosinophils $1 \%$ (70/c.mm.), lymphocytes $37 \% \quad(2,590 /$ c.mm.), and monocytes $7 \%$ (490/c.mm.)). Examination of the blood film showed the red cells to be normocytic and some were a little hypochromic. A few of the red cells contained Howell Jolly bodies. (Subsequent examination of the film showed these to number about 1 per 1,000 red cells.) There was a moderate number of target cells. The presence of the Howell Jolly bodies prompted an inquiry to the ward as to whether he had ever had a splenectomy. When this was denied the matter was forgotten owing to extreme pressure of work. It can, therefore, be said with truth that the absence of this man's spleen was suspected.

Microscopy of the stool on October 24 and November 22 showed a moderate number of undigested muscle fibres and starch granules. No cysts, ova, or parasites were seen. On October 29 a histamine test meal showed no free acid. On November 9 a barium meal radiograph showed:

"Small bowel shows irregular spasm, locally dilated loops, and generalized deficiency pattern but no sign of obstruction. A 24-hour film showed that the small bowel has now emptied and there is a I tendency to double contour throughout the whole colon with numerous apparent string signs and gross disorganization of the mucosal pattern of the distal colon, although the haustral pattern is relatively 
preserved. This suggests a diffuse colitis, but I cannot see any evidence of carcinoma."

On November 9 the patient was too ill to be sigmoidoscoped. On November 20 the serum electrolytes were:

$\begin{array}{lllll}\text { Sodium } & \ldots & 312 & \mathrm{mg} . / 100 \mathrm{ml} .(136 \mathrm{mEq} / 1 .) \\ \text { Potassium } & \ldots & 11.8 \mathrm{mg} . / 100 \mathrm{ml} .(3.01 \mathrm{mEq} / 1 .) \\ \mathrm{NaCl} & \ldots & 618 \mathrm{mg} . / 100 \mathrm{ml} .(106 \mathrm{mEq} / 1 .) \\ \text { Calcium } & \ldots & 8.2 & \mathrm{mg} . / 100 \mathrm{ml} .\end{array}$

An examination of the fat content of the dried faeces on November 21 showed the total fat to be only $5.8 \%$.

On November 23 the patient complained of pain in the hands and on examination had carpopedal spasm due to tetany. This responded well to an intravenous injection of $20 \mathrm{ml}$. of $10 \%$ calcium gluconate. On November 26 his hands were again in tetany and again treatment rapidly relieved it. On this day he was started on potassium chloride, 2 g. t.d.s. by mouth; he was found to have developed pneumonia and was started on a course of penicillin. On November 27 the haemoglobin was $69 \%-10.2 \mathrm{~g} . /$ $100 \mathrm{ml}$., and the serum contained:
Alkaline phosphatase 13.6 units $/ 100 \mathrm{ml}$.
Potassium ... ... $13.9 \mathrm{mg} . / 100 \mathrm{ml}$. (3.57 mEq/1.) Calcium $\quad \ldots \quad \ldots 6.7 \mathrm{mg} . / 100 \mathrm{ml}$.

On November 28 examination of the dried faeces showed evidence of steatorrhoea. The findings were:

$\begin{array}{lcccr}\text { Neutral fat } & \ldots & \ldots & \ldots & 3.1 \% \\ \text { Free fatty } & \text { acids } & \ldots & \ldots & 28.6 \% \\ \text { Soaps } \quad \ldots & \ldots & \ldots & \ldots & 28.5 \% \\ \text { Total } \quad \ldots & \ldots & \ldots & \ldots & 58.2 \%\end{array}$

On December 10 the serum potassium level had risen to $17.1 \mathrm{mg} . / 100 \mathrm{ml}$. $(4.4 \mathrm{mEq} / \mathrm{l}$. $)$ and on December 14 it was $28 \mathrm{mg} . / 100 \mathrm{ml}$. $(7.2 \mathrm{mEq} / \mathrm{l}$.) and the serum calcium was $6.7 \mathrm{mg} . / 100 \mathrm{ml}$. He died later that day.

Post-mortem Findings.-The body was that of a wasted old man. There was a paramedian scar in the right iliac region, but no scar was detected on the left side of the abdomen. There was acute tracheitis and bronchopneumonia with an abscess in the upper lobe of the right lung. The wall of the abscess was adherent to the right second costal cartilage. The heart was normal. The liver showed early cirrhosis. The spleen and splenic vessels were completely absent. This was confirmed by two observers. The gastro-intestinal tract showed only chronic enterocolitis ; no other lesion was detected. Histological examination of the ileum and colon did not throw any light on the cause of the enterocolitis. The appendix was missing. Bacteriological examinations of a swab from the colon showed no organisms of the salmonella or shigella groups, and a swab from the lung abscess grew penicillin-resistant Staphylococcus pyogenes.

\section{Discussion}

The interest of this case lies not only in the record of a very rare congenital anomaly but also it possibly supplies evidence that chronic enterocolitis following a salmonella bowel infection may be due to lack of antibody formation by the spleen. It also raises the question of the diagnostic significance of Howell Jolly bodies in the peripheral blood.

It is not the purpose of this paper to review the vast amount of research that has been done to determine the role of the spleen in antibody formation. A few pertinent facts, however, must be considered. Perla and Marmorston (1935) review all the early animal experiments in a masterly fashion. Their conclusions are worth repeating:

"It is of interest that the resistance to histamine of the rat and mouse free from latent infections is unaffected by splenectomy. This suggests that the drop in natural resistance following splenectomy is not of a general character. It seems to be associated with those diseases and toxaemias which, in normal animals, affect the macrophage tissue of the spleen. The role of the spleen in resistance is due not entirely to the obvious capacity of its macrophage tissue, for phagocytosis and resistance may depend on many subtle chemical relationships which, at present, are little understood."

There is general agreement that, although the spleen has something to do with immunity, splenectomized human beings and also those with congenital agenesis or with atrophy of the spleen are not unduly susceptible to the common infections. It would appear that the reason for this is that in order to produce clinical evidence of an absence of the antibody-forming capacity of the spleen, the nature, dose, and route of entry of the antigen must be just right. Rowley (1950a) showed that in the splenectomized rat the production of circulating antibody is the result of the dosage of antigen and the route of administration. If the dose was small and intravenous there was a low antibody titre, but if it was intraperitoneal or intraportal the titre was as high as in similarly treated normal rats. Working with splenectomized human beings he showed (1950b) that when an intravenous antigen (heterologous erythrocytes) was given they failed to have a significant rise in antibody compared with normal controls. Motohashi (1922) showed that splenectomized animals had a poor antibody response when a small dose of intravenous antigen was given but a good response when the dose was large. He thought that only when the dose was large were other sites of antibody formation stimulated.

It is tempting to ascribe the patient's chronic enterocolitis to deficient antibody formation to a 
small number of salmonella remaining in the intestine and its lymph nodes. This does not, at first sight, fit in with Rowley's (1950a) findings, but a salmonella infection is a generalized septicaemia and a small number of bacilli were probably in the systemic as well as in the portal circulation. The baby quoted by Plowman (1957) had uncontrollable diarrhoea, and one of the cases of atrophy of the spleen quoted by Boveri (1942) had fatty diarrhoea. No post-mortem examination was done on this latter case, and it could have been agenesis and not atrophy of the spleen. Engel (1939) stated that all published cases of uncomplicated non-tropical sprue showed atrophy of the spleen except for one, with the implication that the atrophy was the result of the intestinal disorder. It is also possible to postulate, however, that atrophy or agenesis of the spleen may be a factor in the causation of fatty diarrhoea.

It cannot truthfully be stated that the present case was diagnosed before death and no search for Heinz bodies was therefore made. After the patient died, however, the blood film made on October 29, 1956, was re-examined, the Howell Jolly bodies counted, and the film examined for Heinz bodies; none could, however, be detected. Absence of the spleen was, however, suspected because of the Howell Jolly bodies in the peripheral blood film. The target cells were not considered of diagnostic importance. Whitby and Britton (1957) give an account of the varieties of target cells together with the different conditions in which they are found. It should be emphasized that, according to Boveri (1942), the diagnostic significance of Howell Jolly bodies is limited. He quoted seven cases, one with beriberi, one with carcinomatosis of the abdomen and bone marrow, four with pernicious anaemia (one with associated cholecystitis), and one with chronic enterocolitis, all of which had normal spleens and yet showed
Howell Jolly bodies in the red cells. It is possible, therefore, but unlikely, that the enterocolitis and not the agenesis of the spleen was the cause of the presence of Howell Jolly bodies in the red cells of the man described in this paper.

\section{Summary}

A patient is described with congenital agenesis of the spleen and splenic vessels who had chronic enterocolitis with secondary steatorrhoea. This enterocolitis followed a Salmonella tennessee infection seven years previously. He died of bronchopneumonia and a lung abscess. The possible immunological relationship of the absence of the spleen to the chronic enterocolitis and also the diagnostic significance of Howell Jolly bodies are discussed. This case is the twenty-second in patients over the age of 3 years and the twentyfirst in an adult.

I wish to thank Dr. Stirling Eddie for permission to publish the case history and for his encouragement.

\section{REFERENCES}

Annotation (1957). Brit. med. J., 1, 153.

Boveri, R. M. (1942). Guy's Hosp. Rep., 91, 81.

Bush, J. A., and Ainger, L. E. (1955). Pediatrics, 15, 93

Engel, A. (1939). Nord. med., 1, 388.

Fadell, E. J., Corbett, J. B., and Carrasco, E. D. (1957). Amer. J. clin. Path., $28,71$.

France, N. E. (1957). Brit. med. J., 1, 286

Ivemark, B. I. (1955). Acta pa?diat. (Upp:ala), 44, Suppl. 104, p. 7.

Leadbeater, N. A. G. (1957). Brit. med. J., 1, 342.

Motohashi, S. (1922). J. med. Res., 43, 473.

Myerson, R. M., and Koelle, W. A. (1956). New Engl. J. Med., 254, 1131.

Nihoyannopoulos, J., Zannos, L., Oeconomon-Mavrou, C., and Statherou, E. (1956). J. clin. Path., 9, 323.

Perla, D., and Marmorston, J. (1935). The Spleen and Resistance. Williams \& Wilkins, Baltimore.

Plowman, D. E. M. (1957). Brit. med. J., 1, 147.

Putschar, G. J., and Manion, W. C. (1956). Amer. J. clin. Path., 26 429.

Rowley, D. A. (1950a). J. Immunol., 64, 289.

(1950b). Ibid., 65, 515 .

Towers, B., and Middleton, H. (1956). J. Path. Bact., 72, 553.

Whitby, L. E. H., and Britton, C. J. C. (1957). Disorders of the Blood, p. 70. J. \& A. Churchill, London. 